\title{
Pemodelan Kesediaan Pelajar Beranjak kepada Berbasikal di UKM
}

\author{
(Modelling of Student Readiness Switch to Cycling Modes at UKM) \\ Sahar Abd Ali Dawood, Muhamad Nazri Borhan* \& Riza Atiq Rahmat
}

ABSTRAK

\begin{abstract}
Peningkatan kebergantungan kepada penggunaan kereta dan gaya hidup yang tidak aktif di kampus universiti telah menyebabkan kesesakan lalu lintas yang semakin meningkat dan lebih banyak permintaan untuk tempat letak kereta, pencemaran udara dan lain-lain lagi. Oleh itu, banyak kajian telah dilakukan untuk memenuhi keperluan bagi kelestarian di kampus universiti. Istilah "Pengangkutan Aktif" seperti berbasikal perlu dijadikan cara untuk memperoleh kelestarian di kampus universiti. Untuk menilai kesan langkah ini, sejumlah 169 soal selidik telah diedarkan di dalam kampus kepada pemandu-pemandu kereta dan temuramah telah dilakukan dengan pelajar-pelajar di Universiti Kebangsaan Malaysia (UKM). Regresi logistik telah digunakan untuk menganalisis faktor-faktor yang mempengaruhi pengguna untuk menukar mod perjalanan mereka kepada berbasikal. Dapat disimpulkan bahawa dengan mengenakan bayaran letak kereta dan mengurangkan ruang untuk letak kereta secara langsung akan memberi kesan kepada penggunaan berbasikal sebagai mod pengangkutan di dalam kampus.
\end{abstract}

Kata kunci: Berbasikal; kampus universiti; pengangkutan aktif; UKM

\section{ABSTRACT}

Increasing dependence on the use of cars and sedentary lifestyle in the university campus have resulted in growing traffic congestion and more demand for parking, air pollution, and many others. Therefore, many studies were carried out to fulfil the requirement for sustainability in the university campuses. The term of "Active Transportation" such as cycling needs to be a way to acquire sustainability in the university campuses. In order to evaluate the impact of this measure, a total of 169 questionnaires were distributed personally inside the campus to the car drivers and interviews were conducted among the students in National University of Malaysia (UKM). Logistic regression is used to analyses the factors that influenced users to switch their mode choice to cycling. It is concluded that implementing parking fee and limiting parking area will directly affect the cycling activity inside the campus.

Keywords: Cycling; university campus; active transport; UKM

\section{PENGENALAN}

Pada masa kini, kampus universiti boleh dianggap sebagai sebuah bandar kecil kerana saiz keluasan, populasi, dan kepelbagaian aktiviti kompleks dijalankan di dalam kampus, yang mempengaruhi persekitaran secara langsung dan tidak langsung. Kampus universiti juga menghadapi beberapa masalah seperti kesesakan lalu lintas, terutama pada waktu puncak dan juga masalah kekurangan tempat letak kereta. Kemapanan kampus telah menjadi satu kebimbangan sejagat bagi perancang dan pembuat dasar kerana aktiviti dan operasi universiti mempunyai kesan yang komprehensif mengenai alam sekitar (Alshuwaikhat \& Abubakar 2008). Mempromosikan pengangkutan tidak bermotor seperti berbasikal dan mengurangkan kebergantungan pelajar terhadap kenderaan persendirian seperti kereta merupakan komponen penting untuk mencapai kemapanan dalam kawasan kampus (Randall \& Baetz 2001).

Kehilangan kehijauan di kawasan kampus yang telah digantikan dengan tempat letak kereta dan bangunan, membuat keadaan dan suasana menjadi lebih tidak selesa untuk pengangkutan aktif. Kebelakangan ini, ramai penyelidik telah memberi tumpuan dalam kelestarian kampus universiti. Cole (2003) mentakrifkan bahawa penghuni kampus adalah orang yang bertanggungjawab untuk membantu dan menjaga kesejahteraan individu dan ekosistem di kawasan kampus. Bagi menangani cabaran sosial dan perubahan ekologi yang semakin mencabar dari masa ke semasa, adalah perlu untuk penduduk atau penghuni kampus melibatkan diri secara aktif dalam mengekalkan kelestarian kawasan kampus. Kampus universiti yang lestari hendaklah memastikan persekitaran kampus yang sihat, pemuliharaan sumber, pengurusan alam sekitar yang cekap, pengurangan sisa, pengangkutan hijau, menggalakkan ekuiti dan keadilan sosial.

Alshuwaikhat dan Abubakar (2008) mencadangkan kaedah bersepadu untuk mencapai kampus lestari dan beberapa strategi untuk menjadikan kampus lebih mapan. Sistem pengurusan persekitaran universiti perlu menggalakkan kemapanan melalui cara yang berbeza. Sebagai contoh, kampus hijau termasuk bangunan hijau, pemeliharaan kampus, dan pengangkutan hijau. Ini menunjukkan sistem pengangkutan di kampus universiti 
turut menjadi indikator penyumbang kepada kemapanan kawasan kampus.

Pengangkutan hijau yang sering dipraktikkan adalah sistem pengangkutan aktif yang menggalakkan pelajar berjalan kaki dan berbasikal di kawasan kampus. Dengan mempraktikkan pengangkutan aktif, penggunaan kenderaan persendirian di kampus boleh dikurangkan dan boleh menjadi salah satu strategi untuk mengurangkan kesesakan dan pencemaran. Terdapat sejumlah besar pelajar yang tinggal secara langsung di kolej-kolej kediaman di dalam kampus. Oleh itu, aktiviti berbasikal merupakan pengangkutan yang boleh dipraktik untuk jarak perjalanan yang dekat. Sebagai faedah, tiada pencemaran dan tiada sumber tenaga yang perlu dibazirkan bagi berbasikal (Tolley 1996).

Terdapat beberapa faktor yang turut mempengaruhi penggunaan basikal dan perlu diambil perhatian seperti penyediaan kemudahan untuk berbasikal seperti laluan khas, kehadiran pengawal keselamatan serta penyediaan lampu di setiap laluan bagi mengelakkan kejadian jenayah ke atas penunggang basikal. Selain itu, dasar universiti juga turut menyumbang penggunaan kepada pengangkutan aktif seperti mengenakan bayaran ke atas tempat letak kenderaan bagi kaki tangan universiti (Kaplan 2015; Rybarczyk \& Gallagher 2014). Antara universiti yang berjaya menggalakkan pelajar dan kaki tangannya menggunakan pengangkutan aktif adalah seperti Universiti California, Berkeley, Amerika. Sebanyak $50 \%$ perjalanan di kampus melibatkan pengangkutan aktif samada berjalan atau berbasikal, 20\% perjalanan pula menggunakan pengangkutan awam dan selebihnya iaitu 30\% pula menggunakan kenderaan persendirian (Schneider et al. 2013). Di negara Eropah pula, Belanda mempunyai pengguna basikal paling ramai iaitu sebanyak $27 \%$ perjalanan di negara itu yang menggunakan basikal, diikuti oleh Denmark sebanyak $18 \%$ dan masing-masing $10 \%$ bagi Finland, Jerman, Sweden dan Belgium (Pucher \& Buehler 2008).

Melihat kepada senario ini, kajian ini adalah bertujuan untuk mengkaji faktor-faktor yang mempengaruhi pengguna kereta di dalam kampus di Universiti Kebangsaan Malaysia (UKM) untuk beralih ke mod berbasikal dengan memperkenalkan beberapa langkah seperti pelaksanaan caj tempat letak kereta dan mengurangkan ruang letak kereta di kawasan kampus.

\section{KAEDAH KAJIAN}

Kampus utama Universiti Kebangsaan Malaysia (UKM) yang merupakan kawasan kajian terletak di Bangi, Selangor, kira-kira $35 \mathrm{~km}$ dari Kuala Lumpur dan meliputi kira-kira 1,100 hektar. Pada masa kini, UKM mempunyai 13 fakulti, 16 institusi penyelidikan dan 14 pusat perkhidmatan. Lokasi bagi semua fakulti, institusi dan pusat di UKM adalah seperti ditunjukkan dalam Rajah 1. UKM mempunyai komuniti akademik terdiri daripada 265 profesor; 413 profesor bersekutu; 1974 pensyarah; 115 tutor dan 123 guru serta memiliki kakitangan sokongan lebih dari 3714. Populasi pelajar pula, UKM mempunyai kira-kira 19,371 pelajar sarjana muda dan 12,838 pelajar pasca siswazah di mana 3,347 adalah pelajar asing dari 35 negara yang berbeza.

Kaedah pengumpulan data dijalankan ke atas responden melalui agihan borang soal selidik untuk memperolehi maklumat dan data yang diperlukan. Soal selidik digunakan untuk mendapatkan maklum balas responden tentang pengenalan mod pengangkutan berbasikal dan seterusnya mencadangkan satu dasar untuk menggalakan pelajar menggunakan pengangkutan tidak bermotor seperti berbasikal di UKM. Menurut Ismail (2013) kaedah kaji selidik mempunyai beberapa kelebihan, iaitu boleh menggunakan sampel yang besar dan pendapat ramai diperolehi dalam masa yang cepat. Sebelum aktiviti pengumpulan data sebenar dilakukan, satu pengujian awalan atau lebih dikenali sebagai kajian rintis telah dilakukan bagi memastikan soalan di dalam borang soal selidik tersebut mudah difahami dan mudah dijawab oleh responden. Menurut Cooper dan Schindler (2007), pengujian awalan yang dijalankan adalah untuk mengenalpasti sekiranya ada kesilapan atau kesalahan di dalam reka bentuk instrumentasi yang dijalankan bagi membolehkan penyelidik memperbetulkannya sebelum diguna pakai di dalam kajian sebenar. Berdasarkan kajian awal, sebanyak 20 responden dapat memahami dengan jelas setiap soalan yang dikemukakan di dalam borang kaji selidik.

Kajian soal selidik yang sebenar telah dijalankan di 24 fakulti dan pusat di UKM oleh tiga orang pengumpul data. Dalam kajian ini, kaedah persampelan yang digunakan adalah kaedah persampelan rawak berlapis dalam pendekatan untuk mendapatkan sampel responden. Responden (pemandu kereta sahaja) di dalam kajian ini merupakan pelajar prasiswazah dan juga pelajar pasca-siswazah.

Soal selidik ini telah direka bentuk dalam empat bahagian; Bahagian A merupakan maklumat am responden seperti umur, jantina, dan maklumat peribadi lain. Bahagian B pula berkaitan maklumat perjalanan responden, manakala Bahagian $\mathrm{C}$ tentang pengetahuan dan sikap terhadap penggunaan basikal seperti faktor-faktor yang menggalakkan penggunaan kereta dan faktor-faktor yang tidak menggalakkan penggunaan basikal. Bahagian terakhir, Seksyen D, adalah mengenai maklumat dasar untuk berbasikal di kampus. Maklumat demografi responden adalah seperti di Jadual 1.

\section{STRUKTUR MODEL}

Model regresi logistik digunakan untuk mengira perubahan kemungkinan bagi pemboleh ubah bersandar. Fungsi logistik dalam persamaan (1) yang biasa digunakan dalam pemodelan pengangkutan adalah seperti di dalam persamaan berikut (Hess \& Polak 2004):

$$
P=\frac{1}{1+e^{\left(\alpha+\beta_{1} X_{1}+\beta_{2} X_{2}+\beta_{3} X_{3}+\cdots\right)}}
$$




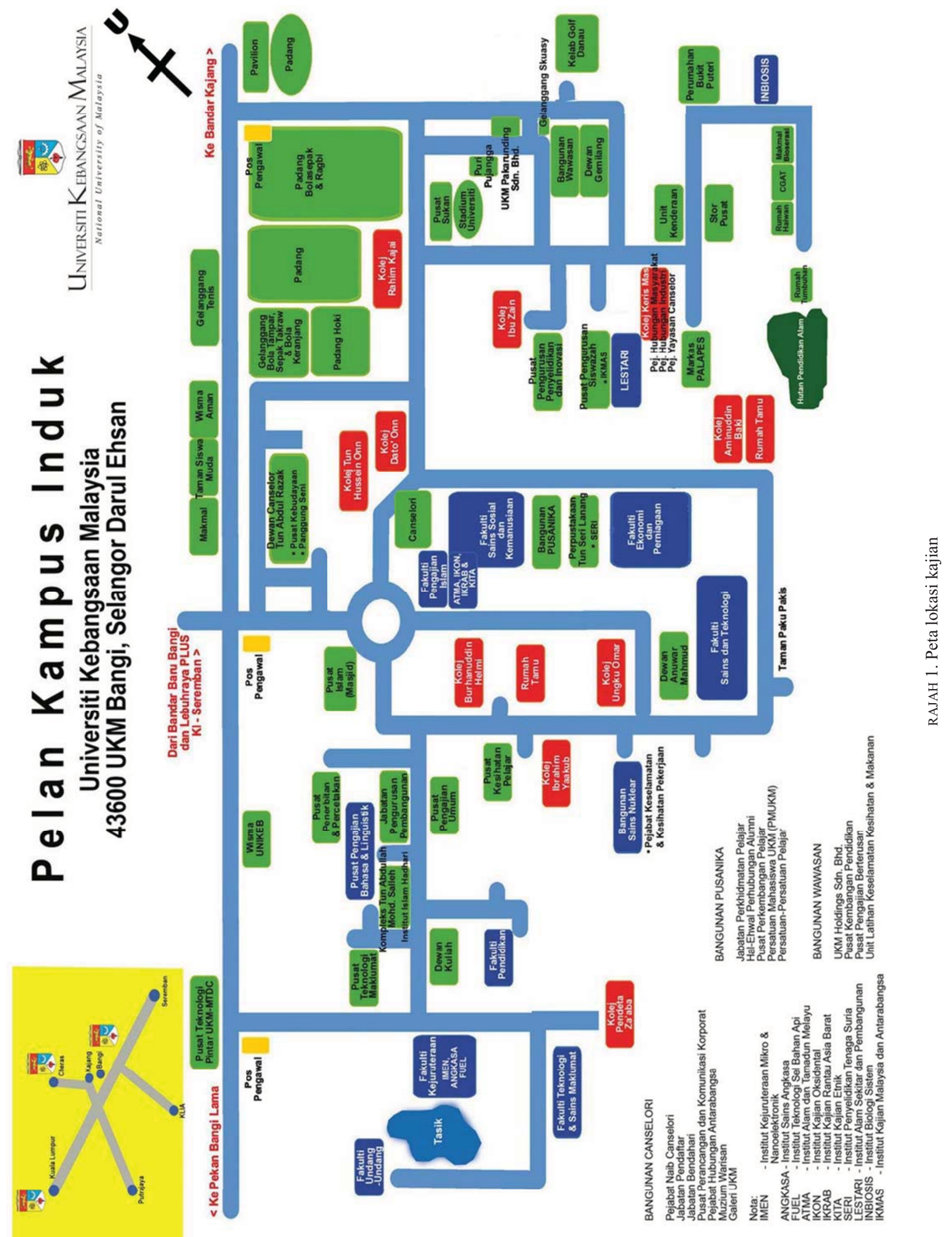


JADUAL 1. Maklumat sosio-demografi responden $(n=169)$

\begin{tabular}{lcc}
\hline & $\mathrm{N}$ & $\%$ \\
\hline Jantina & & \\
Lelaki & 101 & 59.8 \\
Perempuan & 68 & 40.2 \\
& & \\
Umur (Tahun) & & \\
Kurang daripada 23 & 93 & 55.0 \\
23-34 & 49 & 28.9 \\
$35-44$ & 24 & 14.2 \\
$45-54$ & 3 & 1.7 \\
\hline
\end{tabular}

Melalui penjelmaan logaritma, persamaan (1) boleh dijelmakan seperti berikut

$$
\ln \frac{P}{1-P}=\alpha+\beta_{1} X_{1}+\beta_{2} X_{2}+\beta_{3} X_{3}+\cdots
$$

Di sini; $\quad P=$ ialah kebarangkalian,

$$
\alpha=\text { adalah pemalar }
$$$$
\beta_{i}=\text { adalah koefisyen bagi } x_{i}
$$

\section{KEPUTUSAN DAN PERBINCANGAN}

Model pilihan mod iaitu analisis regresi logistik digunakan untuk menguji kepentingan pemboleh ubah dalam menerangkan tingkah laku pilihan mod bagi kajian ini. Jadual 2 menunjukkan keputusan anggaran model regresi logistik menggunakan perisian SPSS. Didapati semua pemboleh ubah tak bersandar dan juga pemalar menunjukkan signifikan terhadap model iaitu kurang daripada lima peratus $(p<0.05)$. Tanda positif pada pekali pemboleh ubah menerangkan peningkatan pemboleh ubah berkaitan akan membawa peningkatan kebarangkalian peranjakan kepada berbasikal. Sebaliknya, tanda negatif pada pekali pemboleh ubah menunjukkan bahawa peningkatan pemboleh ubah berkaitan akan mengakibat kebarangkalian anjakan kepada berbasikal akan menurun.

Berdasarkan nilai pekali, $\beta$ dari Jadual 2, dari persamaan (2) boleh ditulis seperti berikut:

$$
\begin{aligned}
\ln \frac{P}{1-P}= & -4.0964+0.7064 B P+ \\
& +0.0756 M K P-0.4905 B S B
\end{aligned}
$$

Di sini, $P=$ kebarangkalian responden akan menggunakan basikal untuk perjalanan di dalam kampus; $B P=$ bayaran di tempat letak kereta; $M K P=$ pengurangan kawasan tempat letak kereta di kawasan kampus; $B S B=$ basikal disediakan dengan dikenakan bayaran sewa.

Keputusan yang diperoleh daripada model boleh dinyatakan seperti di bawah:

1. Seperti yang dijangkakan, dengan meningkatkan bayaran letak kereta dan mengurangkan ruang letak kereta, kebarangkalian penggunaan kereta akan menurun dan kebarangkalian peranjakkan basikal akan meningkat.

2. Dengan meningkatkan bayaran sewa untuk basikal di stesen basikal yang akan disediakan oleh UKM, kecenderungan untuk beranjak kepada berbasikal di dalam kampus akan menurun.

Rajah 1 menunjukkan pilihan mod pengangkutan bagi responden jika bayaran tempat letak kereta di dalam kampus dikenakan bayaran. Para responden telah ditanya mengenai samada terdapat caj yang dikenakan tempat letak kereta di tempat letak kereta di dalam kampus dan semua responden menyatakan tiada caj yang dikenakan di kawasan kampus. Cuma terdapat kawasan larangan tempat letak kereta bagi pelajar yang diwartakan dengan mengenakan halangan palang di laluan masuk dan keluar kawasan tempat letak kereta yang dikhaskan untuk kakitangan bagi setiap fakulti dan pusat. Responden ditanya jika bayaran tempat letak kereta akan dilaksanakan, adakah mereka akan beralih untuk berbasikal. Keputusan menunjukkan jika bayaran letak kereta sebanyak RM 1 dikenakan, kebarangkalian sebanyak $47 \%$ responden akan beranjak kepada berbasikal. Sekiranya bayaran tempat letak kereta dinaikkan kepada RM 5, kebarangkalian akan beranjak kepada menggunakan basikal akan meningkat kepada 94\% seperti yang ditunjukkan dalam Rajah 2.

Hasil daripada analisis regresi logistik juga menunjukkan jumlah ruang tempat meletak kereta di kawasan kampus turut menjadi pendorong utama pelajar menggunakan kereta di kawasan kampus seperti yang ditunjukkan dalam Rajah 3. Melalui analisis yang dijalankan menunjukkan pengurangan tempat letak kereta sebanyak $10 \%$ hanya meningkatkan kebarangkalian peranjakan kepada berbasikal sebanyak 4\%. Walau bagaimanapun, kebarangkalian peranjakan kepada berbasikal akan meningkat selari dengan pengurangan kawasan tempat letak kereta di kawasan kampus. Dengan pengurangan sebanyak 50\% kawasan tempat letak kereta di kawasan kampus, hampir separuh

JADUAL 2. Anggaran pemboleh ubah yang terdapat dalam analisis regresi logistik

\begin{tabular}{lcccc}
\hline Pemboleh ubah & Pekali, $\beta$ & Standard Error & Nilai- $t$ & Nilai- $p$ \\
\hline Pemalar & -4.096 & 0.915 & -4.479 & 0.001 \\
Bayaran tempat letak kereta & 0.706 & 0.195 & 3.620 & 0.004 \\
Mengurangkan tempat letak kereta & 0.076 & 0.014 & 5.291 & 0.000 \\
Bayaran sewa basikal & -0.490 & 0.195 & -2.514 & 0.029 \\
\hline
\end{tabular}




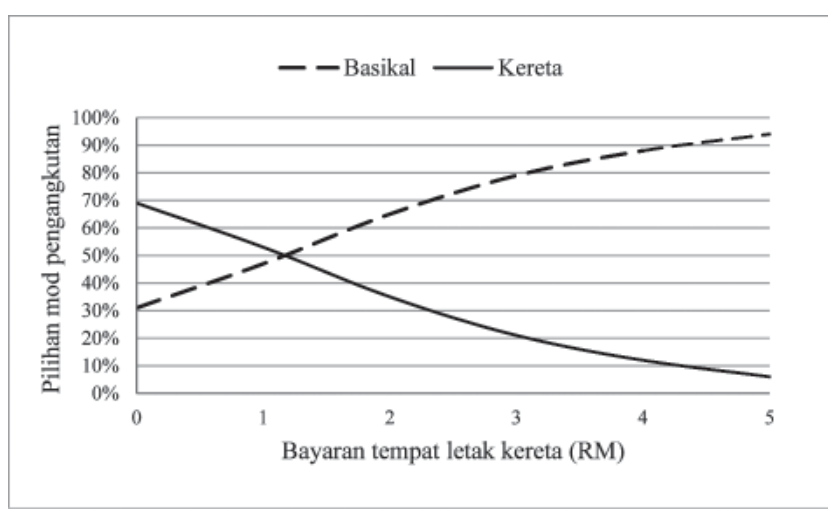

RAJAH 2. Kesan bayaran tempat letak kereta terhadap kebarangkalian pilihan mod pengangkutan

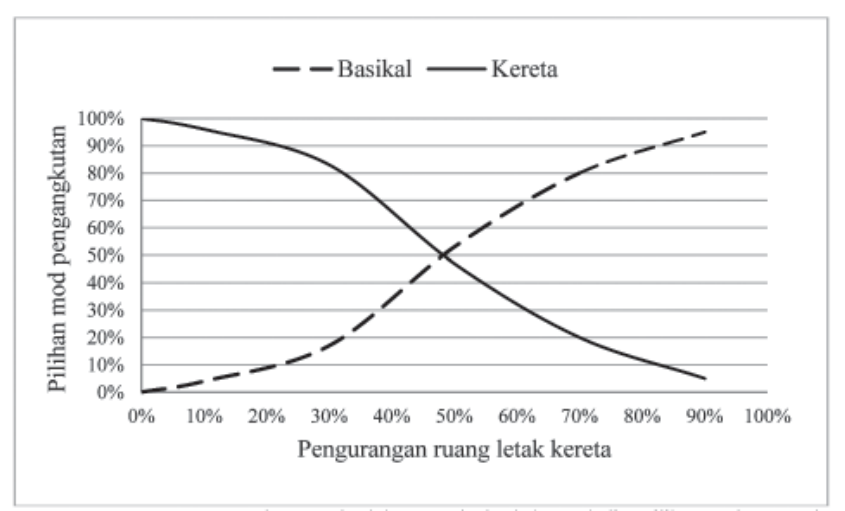

RAJAH 3. Kesan pengurangan kawasan letak kereta terhadap kebarangkalian pilihan mod pengangkutan

responden cenderung untuk memilih berbasikal, dan apabila pengurangan mencapai $90 \%$, majoriti responden akan beralih menggunakan basikal dan bukannya kereta mereka.

Rajah 4 menunjukkan kesan mengenakan bayaran sewa basikal terhadap mod pilihan pengangkutan bagi responden jika UKM menyediakan stesen basikal di dalam kampus. Responden ditanya jumlah sewa yang sesuai untuk menggunakan basikal bagi menggalakkan mereka meninggalkan kereta mereka di kolej kediaman dan menggunakan basikal ke bilik kuliah atau mana-mana tempat di dalam kampus. Sebagai hasil, hanya $11 \%$ menerima untuk menggunakan basikal apabila jumlah sewa adalah RM 5 dan hampir separuh responden (48\%) hanya akan menerima amaun sewa sebanyak RM 1 untuk berbasikal di dalam kawasan kampus.

Kajian ini turut mengutarakan soalan spesifik untuk mengenalpasti faktor-faktor yang paling mungkin akan menggalakkan mereka beralih kepada berbasikal seperti yang ditunjukkan dalam Jadual 3. Sebanyak 28.4\% menyatakan dengan mengenakan bayaran letak kereta pada kadar yang tinggi di kawasan kampus akan menjadi faktor utama peralihan mereka diikuti dengan menyediakan basikal percuma dan lorong berbasikal eksklusif di dalam kampus dengan masing-masing sebanyak $19.5 \%$. Sementara itu,

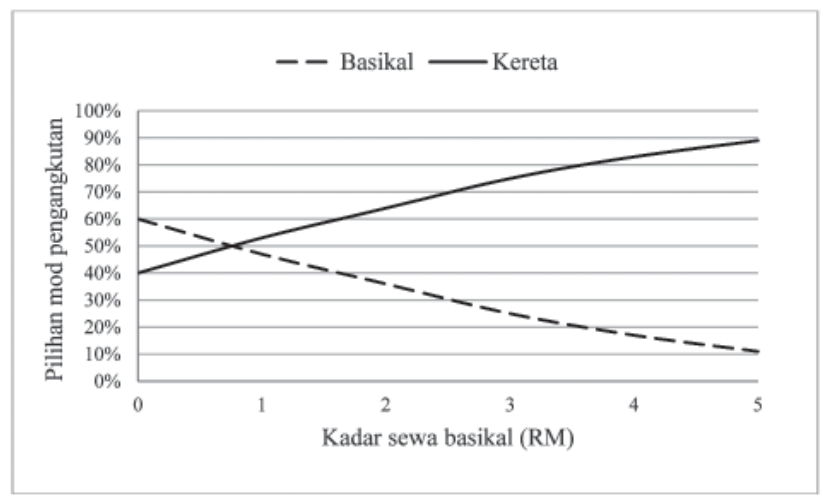

RAJAH 4. Kesan bayaran sewa basikal terhadap kebarangkalian pilihan mod pengangkutan

mengurangkan had laju kenderaan bermotor di jalan raya dan menyediakan tempat letak basikal di kawasan kampus masing-masing menerima purata penilaian sebanyak $17.2 \%$ dan $15.4 \%$.

JADUAL 3. Faktor yang menggalakan responden beralih kepada berbasikal

\begin{tabular}{lc}
\hline Faktor & Peratusan \\
\hline $\begin{array}{l}\text { Mengenakan bayaran letak kereta yang } \\
\text { tinggi }\end{array}$ & 28.4 \\
Mengurangkan had laju kenderaan & 17.2 \\
bermotor di jalan raya & 19.5 \\
Menyediakan basikal percuma & 15.4 \\
Menyediakan tempat letak basikal & 19.5 \\
Menyediakan laluan khas untuk basikal & \\
\hline
\end{tabular}

Selain itu, adalah perlu untuk memahami faktor-faktor yang menghalang pengguna kereta daripada menggunakan basikal sebagai mod pengangkutan ke kuliah atau aktiviti di dalam kampus. Jadual 4 menerangkan penghalang utama yang telah dikenal pasti melalui pilihan responden. Faktor yang paling dominan yang menghalang pengguna kereta bertukar kepada berbasikal adalah masa perjalanan yang semakin meningkat $(29.2 \%)$ apabila responden bertukar mod pengangkutan dari kereta kepada berbasikal. Satu lagi faktor yang turut menyumbang adalah faktor terlibat dengan kemalangan (27.8\%) dan diikuti dengan keselesaan diri, keselamatan, dan keperluan tenaga fizikal.

JADUAL 4. Faktor yang menghalang pengguna kereta daripada bertukar kepada basikal

\begin{tabular}{lc}
\hline Faktor & Peratusan \\
\hline Masa perjalanan & 29.2 \\
Risiko mengalami kecederaan & 27.8 \\
Keperluan tenaga fizikal & 11.8 \\
Keselesaan diri & 15.9 \\
Keselamatan & 15.3 \\
\hline
\end{tabular}


Responden turut ditanya dalam keadaan situasi andaian jika mereka terpaksa menggunakan basikal yang mana berbasikal bukannya mod kebiasaan responden. Lebih separuh daripada responden $(59.3 \%)$ berkata mereka akan berasa tidak selesa dengan rutin mereka dan hanya $26.5 \%$ berkata mereka akan sanggup untuk menggunakan basikal seperti yang ditunjukkan dalam Rajah 5. Sebanyak 59.3\% responden berasa tidak selasa mungkin disebabkan faktor-faktor seperti meningkatkan masa perjalanan ke destinasi iaitu menghadiri kuliah atau sebarang aktiviti mereka di dalam kampus. Selain itu, disebabkan faktor keselamatan juga meningkatkan ketidak-selesaan responden untuk menggunakan basikal untuk melakukan aktiviti perjalanan di kawasan kampus. Ini kerana tiada laluan khas yang disediakan untuk golongan ini dan mereka perlu menggunakan laluan sama yang digunakan oleh kenderaan bermotor yang lain mereka sekiranya mereka bertukar kepada mod berbasikal. Sementara respoden bersa selesa kerana mungkin responden berpendapat berbasikal lebih ekonomi (kurang kos pemilikan, penyelenggaraan dan tiada kos bahan api), menyokong kecergasan fizikal serta lebih mesra alam.

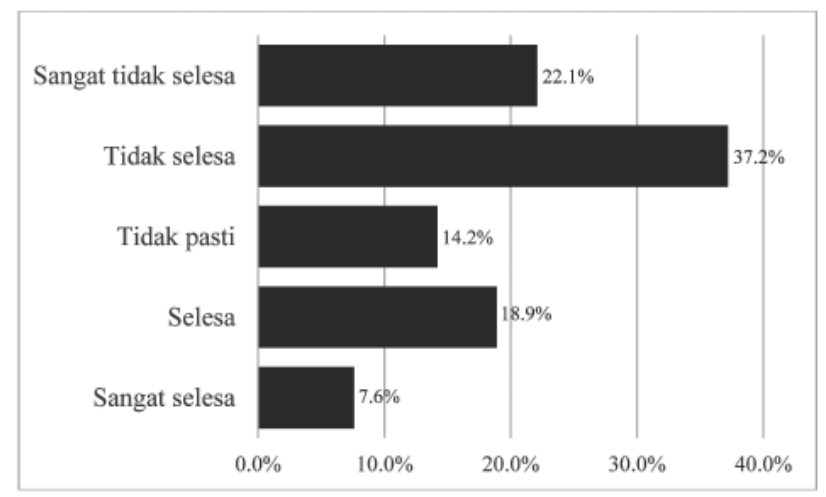

RAJAH 5. Sikap responden terhadap penggunaan basikal sebagai mod pengangkutan

Dapatan kajian menunjukkan pilihan mod pengangkutan dipengaruhi oleh adanya penyediaan kemudahan untuk berbasikal. Faktor utama yang perlu dipertimbangkan dengan mengenakan caj letak kereta bagi pengguna kereta. Dasar mengenakan bayaran di tempat letak kereta telah dikaji sebelumnya, dan ia menunjukkan bahawa pengguna kereta akan mempertimbangkan untuk beralih kepada pengangkutan jenis lain disebabkan berlaku peningkatan kos perjalanan. Pengenalan caj letak kereta akan membuat pengguna kereta untuk membayar lebih. Ini akan meningkatkan kos perjalanan mereka (Borhan et al. 2013). Apabila terdapat perbelanjaan harian meningkat, pengguna kereta akan mencari pengangkutan alternatif lain untuk mengurangkan perbelanjaan mereka (Albert \& Mahalel 2006). Namun, dalam kajian ini, semua responden adalah pelajar dan majoriti daripada mereka tidak mempunyai pendapatan tetap. Oleh itu, bayaran letak kereta dilihat akan memberi pengaruh yang besar ke atas perbelanjaan harian mereka. Menyediakan tempat letak kereta secara percuma merupakan suatu insentif kepada pemandu kereta. Para pengguna kereta merasakan bahawa tidak ada kepentingan bagi mereka untuk menggunakan mod pengangkutan yang lain jika tempat letak kenderaan yang mencukupi dan boleh didapati dengan percuma. Oleh itu, mengenakan caj tempat letak kereta di kawasan kampus akan dapat menggalakkan pengguna kereta beralih ke mod berbasikal di kawasan kampus.

Selain faktor kewangan, faktor lain yang mempengaruhi penggunaan basikal adalah kualiti kemudahan berbasikal. Banyak kajian sebelum ini menekankan kualiti kemudahan berbasikal (Bonham \& Koth 2010, DeMaio 2004, Fishman et al. 2012, Ismail \& Zakaria 2014). Isu utama sebagai penghalang untuk berbasikal adalah isu-isu keselamatan. Berdasarkan pemerhatian kami, jalan-jalan di UKM kurang menyokong kemudahan berbasikal seperti tiada lorong eksklusif untuk berbasikal dan tempat letak kenderaan khusus untuk basikal tidak disediakan. Oleh kerana ketiadaan lorong basikal, penunggang basikal perlu berkongsi laluan dengan kenderaan bermotor yang lain dan ini mencipta isu keselamatan di kalangan penunggang basikal. Pucher (2001) membuat kesimpulan dalam kajiannya menunjukkan bukti yang kukuh bahawa berbasikal adalah lebih selamat dan lebih popular di negara-negara yang menjaga kepentingan penunggang basikal seperti menyediakan lorong basikal, pengubahsuaian persimpangan lampu isyarat untuk memudahkan dan mengutamakan penunggang basikal melepasi lampu isyarat. Sebagai contoh, Belanda dan Sweden mempunyai pisah ragaman yang tinggi untuk berbasikal di kawasan bandar dengan masing-masing pada $27 \%$ dan 20\% (DeMaio 2004). Bilangan pengguna basikal akan bertambah sekiranya banyak kemudahan untuk berbasikal dapat disediakan (Noland \& Kunreuther 1995). Dengan adanya laluan khas basikal di jalan raya akan dapat meningkatkan tahap keselamatan bagi penunggang basikal.

Selain itu, kelakuan pemandu dan kelajuan kenderaan motor turut mempengaruhi pelajar daripada menggunakan basikal untuk membuat perjalanan di dalam kampus. Secara umumnya, kebanyakan pengguna kereta menyangka bahawa tidak ada kepentingan untuk mereka berbasikal. Ini kerana, apabila mereka menukar mod pengangkutan mereka kepada berbasikal, kebimbangan dalam fikiran mereka adalah mengenai tahap kesedaran dan rasa hormat di kalangan pemandu kereta terhadap penunggang basikal. Fishman et al. (2012) telah menemuramah penunggang basikal mengenai tingkah laku pemandu terhadap penunggang basikal. Hasil daripada temuramah tersebut, penunggang basikal mendapati tahap kesedaran dan rasa hormat di kalangan pemandu terhadap penunggang basikal adalah jauh lebih rendah daripada apa yang diharapkan oleh penunggang basikal tersebut. Ini telah menyebabkan pengguna jalan raya untuk lebih memilih untuk terus memandu kereta daripada menukar untuk berbasikal. Selain itu, daripada pemerhatian kami di jalan-jalan UKM, kebanyakan kelajuan kenderaan bermotor sering dipandu laju dan melebihi daripada had kelajuan yang telah ditetapkan di dalam kampus iaitu pada $\operatorname{kadar} 35 \mathrm{~km} / \mathrm{j}$. 
Kajian ini juga mendapati faktor lain yang menggalakkan pelajar untuk beralih kepada berbasikal seperti menyediakan kemudahan berbasikal atau memperkenalkan skim yang serupa dengan konsep 'park and ride' di dalam kawasan kampus iaitu 'park and bike'. UKM juga perlu menyediakan tempat letak basikal dengan sistem kunci untuk mengelakkan masalah kecurian. Di samping itu, dengan mengurangkan tempat letak kereta di kampus itu juga dilihat sebagai cara yang berkesan untuk mengurangkan penggunaan kereta dan menggalakkan penggunaan basikal di dalam kampus. Menurut Shoup (2005), dengan mengurangkan kawasan tempat meletak kenderaan di kawasan tumpuan orang ramai, kemasukan kenderaan persendirian akan dapat dikurangkan.

\section{KESIMPULAN}

Pada hakikatnya, di negara maju seperti Belanda, Denmark, Finland, Jerman, Sweden dan Belgium telah beralih kepada dasar yang lebih memihak kepada pengguna jalan yang tidak bermotor dan masyarakat luar negara telah menjadikan aktiviti kenderaan tidak bermotor sebagai gaya hidup dan pengguna kenderaan tidak bermotor di negara maju tersebut dihormati oleh para pengguna kenderaan bermotor tetapi di Malaysia, malangnya ini tidak digalakkan disebabkan oleh kekangan seperti kemudahan basikal yang tidak mencukupi atau tiada untuk menggalakan penggunaan mod pengangkutan tersebut.

Hasil kajian ini diharapkan dapat memberi sumbangan kepada pihak UKM terhadap pembentukan dasar kenderaan tidak bermotor di dalam UKM untuk menjamin masa depan yang lebih baik seperti konsep pengangkutan mampan untuk kelestarian kampus. UKM perlu mengambil kira pengalaman lepas dan eksperimen bagi negara-negara yang berjaya untuk menggalakkan pengangkutan berbasikal di dalam kampus. Kajian ini masih mempunyai ruang untuk dikembangkan dalam kajian lanjutan di masa depan. Harapan UKM perlu menyediakan beberapa kemudahan untuk menggalakkan berbasikal di dalam kampus seperti laluan khas untuk basikal dan melaksanakan dasar mengenakan bayaran tempat meletak kenderaan serta mengurangkan ruang letak kereta di dalam kawasan kampus.

\section{PENGHARGAAN}

Penulis ingin mengucapkan terima kasih kepada Universiti Kebangsaan Malaysia (UKM) di atas bantuan dan kemudahan yang disediakan dalam menyiapkan kajian ini. Projek ini telah dibiayai oleh UKM di bawah Projek GGPM-2014-062.

\section{RUJUKAN}

Albert, G. \& Mahalel, D. 2006. Congestion tolls and parking fees: A comparison of the potential effect on travel behavior. Transport Policy 13: 496-502.
Alshuwaikhat, H. M \& Abubakar, I. 2008. An integrated approach to achieving campus sustainability: assessment of the current campus environmental management practices. Journal of Cleaner Production 16: 17771785.

Bonham, J. \& Koth, B. 2010. Universities and the cycling culture. Transportation Research Part D 15: 94-102.

Borhan, M. N., Rahmat, R. A. A. O. K., Ismail, A. \& Akhir, N. M. 2013. Kesan masa perjalanan bas dan bayaran tempat letak kereta terhadap penggunaan pengangkutan awam di Putrajaya. Jurnal Teknologi (Sciences \& Engineering) 61(1): 67-71.

Cole, L. 2003. Assessing Sustainability on Canadian University Campuses: Development of a Campus Sustainability Assessment Framework. Canada: Royal Roads University.

Cooper, D. R. \& Schindler, P. S. 2007. Business Research Method. Edisi ke-9. New York: McGraw Hill.

DeMaio, P. 2004. Will smart bikes succeed as public transportation in the United States? Journal of Public Transportation 7(2): 1-14.

Fishman, E., Washington, S. \& Haworth, N. 2012. Barriers and facilitators to public bicycle scheme use: A qualitative approach. Transportation Research Part F 15: 686-698.

Hess, S. \& Polak, J. W. 2004. Analysis of Parking Behavior Using Discrete Choice Models Calibrated on SP Datasets. London: Center for Transport Studies, Imperial College London.

Ismail, A. \& Zakaria, S. 2014. Development of bicycle shift models in Universiti Kebangsaan Malaysia campus. Jurnal Kejuruteraan 26(2014): 69-76.

Ismail, R. 2013. Metodologi Penyelidikan Teori dan Praktis. Bangi: Penerbit Universiti Kebangsaan Malaysia.

Kaplan, D. H. 2015. Transportation sustainability on a university campus. International Journal of Sustainability in Higher Education 16(2): 173-186.

Noland, R. \& Kunreuther, H. 1995. Short-run and long-run policies for increasing bicycle transportation for daily commuter trips. Transport Policy 2(1): 67-79.

Pucher, J. 2001. Cycling safety on bikeways vs. roads. Transportation Quarterly 55(4): 9-11.

Pucher, J. \& Buehler, R. 2008. Making cycling irresistible: lessons from the Netherlands, Denmark, and Germany. Transport Reviews 28(4): 495-528.

Randall, T. A. \& Baetz, B. W. 2001. Evaluating pedestrian connectivity for suburban sustainability. Journal of Urban Planning and Development 127(1): 1-15.

Rybarczyk, G. \& Gallagher, L. 2014. Measuring the potential for bicycling and walking at a metropolitan commuter university. Journal of Transport Geography 39: 1-10.

Schneider, R. J., Grembek, O., Braughton, M., Orrick, P. \& Ragland, D. R. 2013. Pedestrian and Bicycle Safety Strategies for UC Berkeley Campus and Periphery: Recommendations for Implementation. California: Safe Transportation Research \& Education Center, University of California. 
Shoup, D. 2005. The High Cost of Free Parking. Chicago: American Planning Association, Chicago, IL.

\author{
Sahar Abd Ali Dawood \\ Muhamad Nazri Borhan* \\ Riza Atiq Rahmat \\ Pusat Penyelidikan Pengangkutan Bandar Mapan (SUTRA), \\ Jabatan Kejuruteraan Awam dan Struktur, \\ Fakulti Kejuruteraan dan Alam Bina, \\ Universiti Kebangsaan Malaysia
}

*Penulis koresponden; emel: mnazri@eng.ukm.my

Tarikh serahan: 30 Mac 2015

Tarikh terima: 27 Mei 2015
Tolley, R. 1996. Green campuses: cutting the environmental cost of commuting. Journal of Transport Geography 4(3): 213-217. 